\title{
ANALISIS TRADING VOLUME ACTIVITY DAN AVERAGE ABNORMAL RETURN SEBELUM DAN SESUDAH MELAKUKAN PEMECAHAN SAHAM (STOCK SPLIT) PADA PERUSAHAAN YANG TERDAFTAR DI BURSA EFEK INDONESIA.
}

\author{
Anita Tri Utami \\ Universitas Islam Sultan Agung Semarang \\ anitatriutami893@gmail.com
}

\begin{abstract}
ABSTRACK
This research is titled "Analysis of Trading volume activity and Average Abnormal Return before and after the stock split pada companies listed on the bursa efek indonesia" . this research aims to analysing is there any differences between the abnormal return and the trading volume activity before and after the stock split. The data that have been used in this research are the daily stock price and the IHSG of the companies who did the stock split in 2011 till 2015.By the purposive sampling methods, there is 32 companies who did the stock split that listed on the bursa efek indonesia. Analysis technique that has been used is Uji normalitas dan uji beda dua sampel berhubungan uji wilcoxon with the event window is 5 days before and 5 days after the stock split. The result of this research is show that there is $0,024<0,05$ significant value from the Pengujian Uji Beda between trading volume activity before and trading volume activity after stock split. Based on that fact, there is 0,033 < 0,05 significant value from pengujian uji beda between abnormal return before and bid-ask spread after the stock split. Thus can be interpreted that there is a difference between abnormal return before and after stock split. So that the Indonesia Capital market is yet efficient and yet strong enough by the stock split.
\end{abstract}

Kaywords: Stock split, Abnormal Return, Trading volume activity.

\section{PENDAHULUAN}

Pasar modal merupakan alternatif investasi jangka panjang dan sebagai media investasi bagi investor. Tiaptiap pilihan investasi mempunyai tingkat keuntungan dan risiko yang berbeda-beda pula. Bahkan,tingkat keuntungan dan risiko antar saham pun akan berbeda sekalipun dalam sektor industri yang sama. Hal ini disebabkan oleh adanya perbedaan faktor internal (manajemen, pemasaran, keadaan keuangan, kualitas produk, dan kemampuan bersaing) dan faktor eksternal (kebijakan pemerintah, pesaing, serta selera dan daya beli masyarakat) (Suryantini, 2007:300).
Berbagai jenis transaksi yang dilakukan di pasar modal,saham merupakan transaksi yang menarik dilakukan. Perusahaan yang menerbitkan sahamnya sangat memperhatikan nilai dari harga saham. Nilai dari harga saham tinggi akan menurunkan tingkat permintaan saham, sebaliknya jika harga saham rendah maka permintaan saham tersebut juga akan meningkat. Permata (2012) mengatakan bahwa dengan melakukan tindakan stock split membuat harga saham menjadi murah dan akan menarik investor.

Kalay and Mathias (2013) manajer memilih untuk melakukan pemecahan 
saham karena mereka berpikir bahwa tidak mungkin harga saham akan turun ke kisaran yang diinginkan tanpa melakukan pemecahan saham. Menurut Rudnicki (2012) manajer melakukan stock split untuk meningkatkan kepemilikan saham investor kecil yang dianggap sebagai penyedia likuiditas. Semakin tinggi transaksi saham tersebut, maka likuiditas terhadap saham tersebut juga akan meningkat.

Carlos (2009) pengumuman stock split mempengaruhi harga saham perusahaan, bahwa harga saham bereaksi sangat cepat ke semua informasi publik dan investor dapat memperoleh pengembalian di atas normal setelah pengumuman dibuat. Pemecahan saham diharapkan juga akan memberikan return pada pemegang saham. Pemecaham saham yang akan memperkecil harga saham memungkinkan transaksi atas saham meningkat dan akan memberikan peluang untuk memperoleh abnormal return Fama et al. (dalam Wijanarko, 2012).

Pada dasarnya ada dua jenis pemecahan saham yang dapat dilakukan,yaitu pemecahan naik (split up) dan pemecahan turun (split down/reverse split) pemecahan naik adalah penurunan nilai nominal per lembar saham yang mengakibatkan bertambahnya jumlah saham yang beredar misalnya pemecahan saham dengan faktor $2: 1,3: 1$, dan 4:1. Sedangkan pemecahan turun adalah peningkatan nilai nominal per lembar saham,dan mengurangi jumlah saham yang beredar. Misalnya pemecahan turun dengan faktor pemecahan 1:2, 1:3, dan 1:4.

Menurut Baker dan Gallangher (dikutip dari Marwata, 2001) salah satu tujuan stock split adalah untuk mengembalikan harga per lembar saham pada tingkat perdagangan yang optimal sehingga meningkatkan likuiditas. Peneltian terdahulu berpendapat bahwa pemecahan saham hanya merupakan distribusi saham yang semata mata memiliki perubahan yang sifatnya "kosmetik", dalam arti bahwa tindakan tersebut merupakan upaya agar lebih menarik di mata investor sekalipun tidak meningkatkan kemakmuran dari investor. Tindakan pemecahan saham akan menimbulkan efek fatamorgana bagi investor,yaitu investor merasa menjadi lebih makmur karena memegang saham dalam jumlah banyak.

Meskipun secara teoritis pemecahan saham tidak memiliki nilai ekonomis akan tetapi banyak peristiwa di pasar modal yang menunjukkan bahwa pemecahan saham merupakan peristiwa yang penting dalam praktik pasar modal. Pemecahan saham yang menjadikan harga saham lebih murah diharapkan akan mampu menjaga tingkat perdagangan saham dalam rentang yang optimal dan menjadikan saham semakin likuid. Harga saham yang murah akan meningkatkan volume perdagangan saham,(Alfian Dody Firmansyah,2016).

Peristiwa stock split sampai sekarang ini merupakan fenomena yang masih diperdebatkan para ahli di bidang ekonomi,hal ini ditunjukan dengan adanya ketidakcocokan antara teori dan praktek.Secara teoritis,stock split hanya meningkatkan jumlah lembar saham yang beredar dan tidak secara langsung mempengaruhi cash flow perusahaan. Sementara dalam prakteknya terdapat beberapa bukti empiris yang menunjukan bahwa pasar memberikan reaksi terhadap peristiwa ini,meskipun reaksi tersebut tidak sepenuhnya disebabkan oleh pengumuman stock split,tetapi juga disebabkan oleh kondisi efisiensi dari pasar modal di negara bersangkutan.

\section{KAJIAN PUSTAKA}

\section{Signaling Theory}

Signalling theory adalah bahwa setiap tindakan mengandung informasi karena adanya asymetric information. Asymetric information adalah kondisi dimana suatu pihak memiliki informasi yang lebih banyak dari pada pihak lain. Misalnya,pihak manajemen perusahaan memiliki informasi 
yanglebih banyak dibandingkan dengan pihak investor di pasar modal. (Pramastuti, 2007).

Menurut Fahmi (2011) memahami bahwa kebijakan suatu perusahaan melakukan stock split adalah menggambarkan tentang kondisi suatu perusahaan yang sehat terutama dari segi keuangan perusahaan. Huang et al. (2002) Pemecahan saham dilakukan untuk menata harga saham pada rentang perdagangan yang disukai.

\section{Trading Range Theory}

Menurut trading range theory, pemecahan saham digunakan sebagai alat untuk mengatur kembali harga saham pada kisaran harga yang diinginkan sehingga semakin memungkinkan bagi investor untuk membeli dalam jumlah yang banyak. Jika harga padapre-split tinggi,maka pemecahan saham semakin menguatkan kebenaran akan motif tersebut ( Leung, et al, 2005 ).

Trading range theory menjelaskan bahwa pemecehan saham digunakan untuk mengatur kembali harga saham di kisaran harga tertentu, agar investor mampu membeli saham tersebut (Hendrawijaya, 2009). Saham yang harganya dinilai terlalu tinggi menyebabkan saham tersebut kurang aktif untuk diperdagangkan. Mahalnya harga saham tersebut yang menjadi motivasi perusahaan untuk melakukan pemecahan saham.

\section{PasarModal}

Pasar modal pada hakekatnya adalah pasar yang tidak berbeda jauh dengan pasar tradisional yang selama ini kita kenal, dimana ada pedagang,pembeli dan juga tawar menawar harga. Pasar modal dapat juga diartikan sebagai sebuah wahana yang mempertemukan pihak yang membutuhkan dana dengan pihak yang menyediakan dana sesuai dengan aturan yang ditetapkan oleh lembaga dan profesi yang berkaitan dengan efek. Pasar modal mempunyai posisi yang strategis dalam pembangunan ekonomi nasional.

\section{Pasar Modal yang Efisien}

Pengertian "pasar modal yang efisien" telah digunakan dalam beberapa konteks untuk menjabarkan karakteristik operasi pasar modal. Terdapat perbedaan antara pasar modal yang efisien secara operasional (efisien secara internal) dengan pasar modal yang efisien dalam penetapan harga (efisien secara eksternal) (Jogiyanto, 2003). Dalam pasar yang efisien secara operasional, para investor dapat memperoleh kualitas jasa transaksi yang sebanding dengan biaya intrinsik yang dikeluarkannya untuk mendapatkan jasa-jasa tersebut. Jadi, dalam pasar yang efisien secara internal, setiap tambahan biaya transaksi selalu diimbangi dengan peningkatan kualitas jasa transaksi. Efisiensi penetapan harga mengacu pada pasar di mana harga-harga pada setiap saat sepenuhnya mencerminkan semua informasi yang tersedia sesuai dengan penilaian sekuritas.

Pasar modal efisien terbagi menjadi tiga tingkat (Pandji, 2001), yaitu:

Pasar efisien bentuk lemah (weakform). Adalah suatu pasar modal dimana harga saham sekarang merefleksikan semua informasi historis (seperti harga dan volume perdagangan dimasa lalu). Lebih lanjut informasi masa lalu dihubungkan dengan harga saham untuk membantu menentukan harga saham sekarang. Oleh karena itu, informasi historis tersebut tidak bias langsung digunakan untuk memprediksi perubahan dimasa yang akan datang karena sudah tercermin pada harga saham saat ini. Berbagai kecenderungan harga dapat ditemukan oleh analisis kecenderungan informasi masalalu. Jadi, pasar modal efisien bentuk lama, harga saham mengikuti kecenderungan tersebut

\section{Pasar efisien bentuk setengah kuat (semi strong) \\ Pasar efisien bentuk setengah kuat adalah pasar dimana harga saham pada pasar modal menggambarkan semua}


informasi yang dipublikasikan (seperti earning,deviden, pengumuman, stock split, penerbitan saham baru dan kesulitan keuangan yang dialami perusahaan) sampai kemasyarakat keuangan. Tujuannya adalah untuk meminimalkan ketidaktahuan mengenai operasi perusahaan dan dimaksudkan untuk menjelaskan dan menggambarkan kebenaran nilai dari suatu efek yang telahdi keluarkan oleh suatu institusi.

\section{Pasar efisien bentuk kuat (strongform)}

Pasar modal yang efisien dalam bentuk kuat merupakan tingkat efisien pasar yang tertinggi (konsep pasar yang tertinggi). Konsep pasar efisien bentuk kuat mengandung arti bahwa semua informasi direfleksikan dalam harga saham baik informasi yang dipublikasikan maupun informasi yang tidak dipublikasikan (private information),sehingga dalampasarbentukini tidak akan ada seorang investorpun yang bisa memperoleh abnormal return. Private Information adalah informasi yang hanya diketahui oleh orang dalam dan bersifat rahasia karena alasan strategi.

\section{Event Study}

Event study merupakan studi yang mempelajari reaksi pasar terhadap suatu peristiwa yang informasinya dipublikasikan sebagai suatu pengumuman. Event study dapat digunakan untuk menguji kandungan informasi dari suatu pengumuman dan dapat juga digunakan untuk menguji efisiensi pasar setengah kuat ( Jogiyanto, 2000 ).

\section{Pemecahan Saham}

Pemecahan saham/Stock split adalah suatu aktifitas yang dilakukan oleh para manajer perusahaan dengan melakukan perubahan terhadap jumlah saham yang beredar dan nominal per lembar saham sesuai dengan split factomya (Szewezyk dan Tsetsekos, 1993 dalam Beni Suhendra Winarso, 2005). Pada dasarnya ada dua jenis pemecahan saham yang dapat dilakukan, yaitu pemecahan naik (splitup) dan pemecahan turun (splitdown/ reversesplit).

\section{Volume Perdagangan Saham}

Volume perdagangan saham merupakan rasio antara jumlah lembar saham yang diperdagangkan pada waktu tertentu terhadap jumlah saham yang beredar pada waktu tertentu (Suad Husnan dkk, 2005). Jumlah saham yang diterbitkan tercermin dalam jumlah lembar saham saat perusahaan tersebut melakukan emisi saham.

Volume perdagangan saham merupakan rasio antara jumlah lembar saham yang diperdagangkan pada waktu tertentu terhadap jumlah saham yang beredar pada waktu tertentu (Suad Husnan dkk, 2005). Jumlah saham yang diterbitkan tercermin dalam jumlah lembar saham saat perusahaan tersebut melakukan emisi saham.

\section{Abnormal Return}

Kuse and Takeshi (2008) Stock split merupakan suatu peristiwa yang memiliki efek positif pada return dan memicu kenaikan harga saham. Abnormal return merupakan selisih antara return realisasi (actual return) dan return ekspektasi (expected return). Return ekspektasian merupakan return yang harus diestimasi. Jogiyanto (2010) mengestimasi return ekspektasian menggunakan model estimasi mean-adjusted model, market model dan market-adjusted model. Abnormal Return atau excess return merupakan kelebihan dari actual return (return yang sesungguhnya terjadi) terhadap normal return,dimana normal return merupakan expected return (return yang diharapkan investor), dengan demikian return yang tidak normal (abnormal return) adalah selisih antara return yang sesungguhnya terjadi dengan return ekspektasi (Jogiyanto, 2000).

Dari penjelasan materi-materi dan 
hasil penelitian sebelumnya, maka peneliti menentukan hipotesis sebagai berikut:

$\mathrm{H} 1$ = Ada Perbedaan trading volume activity sebelum dan sesudah stock split.

$\mathrm{H} 2$ = Ada perbedaan Average Abnormal Return sebelum dan sesudah stock split.

\section{METODE PENELITIAN}

Penelitian ini merupakan Jenis data yang digunakan adalah data kuantitatif yaitu data yang berupa kumpulan angka-angka dari penutupan harga saham dan volume perdagangan saham harian di Bursa Efek Indonesia.

Sumber data dalam penelitian ini berasal dari data sekunder,yaitu data yang dikumpulkan oleh pihak lain (sudah tersedia). Sumber data dalam penelitian ini di peroleh dari data base Bursa Efek Indonesia yang di download melalui situs www.idx.co.id, dan media lain yang mendukung penelitian ini.

Dalam penelitian ini, penelitian menggunakan metode penelitian yaitu dengan metode pengamatan peristiwa yang dalam penelitian ini dapat di lihat dan dianalisi dan pengamatan data yang di dapat dari sumber. Studi peristiwa (event study) disebut juga dengan nama analisis residual (residual analysis) atau pengujian indeks kinerja tak normal(abnormal performance index test) atau pengujian reaksi pasar (market reaction test). Tanggal pengumuman Stock Split (event date) merupakan tanggal dimana pemecahan saham diumumkan oleh perusahaan kepada publik melalui Bursa efek Indonesia. Penetapan tanggal pengumuman pemecahan saham digunakan $t=0$ yaitu tanggal diumumkannya pemecahan saham. Periode pengamatan (event window ) yang digunakan dalam penelitian ini adalah 10 hari bursa yang di bagi menjadi 2 yaitu $\mathrm{t}=-5$ (5 hari sebelum stock split) dan $\mathrm{t}=$ 5 (5 hari sesudah stock split). Pemilihan periode pengamatan tersebut didasarkan pada pendekatan penelitian Brown dan Warner. Diman peristiwa pengumuman stock split merupakan peristiwa yang nilai ekonomisnya dapan ditentukan dengan mudah oleh investor sehingga reaksi investor berlangsung secara tepat serta untuk menghindari terjadinya confounding effect yaitu dampak tercampurnya suatu peristiwa yang di amati dengan peristiwa lain (jogianto,2000).

Sugiyono (2005:72)"populasi wilayah generelisasi yang terdiri atas objek/subjek yang mempunyai kualitas dan karakteristi tertentu yang di tetapan oleh peneliti untuk dipelajari dan kemudian di tarik kesimpulan.".populasi yang digunakan dalam penelitian ini adalah adalah perusahaan yang terdaftardi BEI yang melakuan pemecahan saham.

Sampel adalah bagian dari jumlah karakteristik yang dimiliki oleh populasi tersebut, Sugiyono (2005:73). Jadi sampel meupakan sebagian dari populasi untuk mewakili karakteristik ppulasi yang diambil ntuk keperluan penelitianTehnik penentuan sampel dalam penelitian ini adalah dengan menggunakan purposive sampling. Tehnik ini ditentukan untuk memilih anggota sampel secara khusus secara khusus berdasarkan tujuan penelitian dan kesesuaian criteriakriteria yang telah di tetapkan oleh penelitian.

Teknik pengambilan data dilakukansecara purposive sampling,yaitu pemilihan atau penarikan sampel berdasarkan penilaian terhadap karakteristik anggota sampel yang disesuaikan dengan tujuan penelitian (Suharyadi dan Purwanto 2004,332), Kriteria kriteria yang digunakan dalam penelitian ini adalah sebagai berikut: Perusahaan tersebut listing di BEI selama tahun 20112015. Perusahaan tersebut tidak melakukan corporate action lain, seperti right issue, pembagian deviden dan pembagian saham bonus. Sampel saham yang dipilih aktif diperdagangkan selama periode pengamatan 5 hari seputar pemecahan saham. Datanya tersedia secara lengkap.

\section{Alat analisis}

Uji Beda Dua Sampel Berhubungan Uji 
Wilcoxon (Jika Non Parametrik)

Asumsi, Jika uji normalitas sebelumnya menunjukkan hasil yang tidak signifikan, yaitu jika Asymp. Sig $\alpha<0,05$ maka uji hipotesisnya menggunakan uji beda dua rata-rata wilcoxon.

Uji hipotesis menggunakan wilcoxon ini merupakan suatu pengujian yang di gunakan untuk mengetahui ada tidaknya perbedaan antara dua sampel dependen yang berpasangan atau berkaitan dan digunakan sebagai alternatif pengganti uji Paired sample $t$ test jika data tidak berdistribusi normal. Uji wilcoxon cocok digunakan apabila kita tidak hanya mengetahui besarnya setiap beda tetapi juka arah harga pengamatan yang bersangkutan,maka kita dapat menetapkan peringkat untuk masingmasing beda tersebut uji wilcoxon berfungsi untuk menguji perbedaan antar data berpasangan,menguji komparasi antar dua pengamatan sebelum dan sesudah (Before after design) dan mengetahui efektivitas suatu perlakuan dengan tingkat Signifikansi dan penentuan hipotesis yang sama seperti dalam uji paired sample t-test yaitu $\alpha=0,05$ atau $5 \%$.

\section{HASIL DAN PEMBAHASAN}

Gambaran return saham perusahaan yang melakukan stock split tahun 2011-2015 ada dalam tabel 1 .

Trading volume activity 5 hari sebelum pengumuman stock split sebesar 0,00759438 lebih rendah dibandingkan Trading volume activity 5 hari setelah pengumuman stock split, yaitu sebesar 0,07143881 . Nilai rata-rata Trading volume activity 5 hari sebelum pengumuman stock split sebesar 0,00759438 lebih kecil dari nilai standar deviasi sebesar 0.008506 , artinya data Trading volume activity 5 hari sebelum pengumuman stock split adalah terdistribusi tidak merata, karena memiliki selisih yang tinggi dari data satu dengan yang lainnya. Nilai rata-rata Trading volume activity 5 hari sesudah pengumuman stock split sebesar 0,07143881 lebih kecil dari nilai standar deviasi sebesar 0,129692, artinya data Trading volume activity 5 hari sesudah pengumuman stock split menunjukkan penyimpangan dari nilai rata-ratanya atau terdistribusi tidak merata, karena memiliki selisih yang tinggi dari data satu dengan yang lainnya.

Semakin meningkat volume penawaran dan permintaan suatu saham, semakin besar pengaruhnya terhadap fluktuasi harga saham di bursa efek indonesia,dan semakin meningkatnya volume perdagangan saham menunjukkan semakin di minatinya saham tersebut di masyarakat kemungkinan trading volume activity meningkat artinya perdagangan saham menjadi aktif.

Abnormal return 5 hari sebelum pengumuman stock split sebesar -0,010688 lebih rendah dibandingkan Abnormal return 5 hari setelah pengumuman stock split, yaitu sebesar 0,23021. Nilai rata-rata Abnormal return 5 hari sebelum pengumuman stock split sebesar $-0,010688$ lebih kecil dari nilai standar deviasi sebesar 0,3273 , artinya data Abnormal return 5 hari sebelum pengumuman stock split adalah terdistribusi tidak merata, karena memiliki selisih yang tinggi dari data satu dengan yang lainnya. Nilai rata-rata Abnormal return 5 hari sesudah pengumuman stock split sebesar 0,2302 lebih besar nilai standar deviasi sebesar 0,2296, artinya data Abnormal return 5 hari sesudah pengumuman stock split adalah terdistribusi merata, karena memiliki selisih yang tinggi dari data satu dengan yang lainnya. Apabila terjadi Abnormal Return setelah memecahan saham dapat memberikan keuntungan diatas normal pada investor dan sebaliknya jika terdapat Abnormal return yang negatif menunjukkan bahwa keuntungan yang diperoleh dibawah normal, Kemungkinan Abnormal Return meningkat sehingga pelaku pasar bisa memperoleh Abnormal return.

\section{Uji Normalitas}

Distribusi data normalitas bertujuan untuk menguji apakah dalam model 
Tabel 1

Daftar Perusahaan Melakukan Stock split Tehun 2011-2015

\begin{tabular}{|c|c|c|}
\hline Nama Perusahaan & Kode & Tgl Stock Split \\
\hline Intraco Penta & INTA & 16-Jan-11 \\
\hline Plaza Indonesia & PLIN & 26-Des-11 \\
\hline Pelayanan Tempura Emas & TMAS & 17-Mar-11 \\
\hline Arpeni Pratama Osean Line & APOL & 24-Okt-11 \\
\hline Lippo Karawaci & LPKR & 28-Jul-11 \\
\hline Jaya Real Property & JRPT & 04-Agust-11 \\
\hline Sentul City & BKLS & $10-O k t-11$ \\
\hline Jaya Pary Steel & JPRS & 12-Des-12 \\
\hline Semen Gersik & SMGR & 07-Agust-12 \\
\hline Aneka Tambang & ANTM & 12-Jul-12 \\
\hline Chaeron Pokhphan Indonesia & CPIN & 01-Nop-12 \\
\hline Berlina & BRNA & 04-Agust-13 \\
\hline Panorama Sentrawisesa & PARN & $11-F e b-13$ \\
\hline Island Concept Indonesia & ICON & 10-Des-13 \\
\hline Timah & TINS & 08-Agust-13 \\
\hline International Nikel Indonesia & $\mathrm{INCl}$ & 15-Jan-13 \\
\hline Delta Dunia Makmur & DOID & 15-Apr-13 \\
\hline Surya Inti Semesta & SIIP & 12-Mar-13 \\
\hline Pakuwon Jati & PWON & 19-Sep-13 \\
\hline Panin Securitas & PANS & 21-Jan-13 \\
\hline HD capital & DADE & 15-Jan-13 \\
\hline Arwana Citra Mulia & ARNA & 11-Sep-14 \\
\hline Citra Tubindo & CTBN & 12-Jan-14 \\
\hline Plaza Indonesia & PLIN & 26-Des-14 \\
\hline Darya Varia Laboratoria & DVLA & 12-Nop-15 \\
\hline Tunas Ridean & TURI & 17-Jun-15 \\
\hline Resource Alam Indonesia & $\mathrm{KKGI}$ & 18-Mar-15 \\
\hline Chaeron Pokhphan Indonesia & CPIN & 08-Des-15 \\
\hline Interland Development & DIDL & 22-Jul-15 \\
\hline Ciputra Develpoment & CTRA & 15-Jun-15 \\
\hline Sentul City & BKLS & 10-Okt-15 \\
\hline Pelayanan Tempura Emas & TMAS & 17-Mar-15 \\
\hline
\end{tabular}

Sumber : data sekunder, tahun 2017 
pengujian Trading volume activity sebelum pengumuman stock split, Trading volume activity sesudah pengumumam stock split, bid-ask sebelum pengumuman stock split, bid-ask sesudah pengumumam stock split, abnormal return sebelum pengumuman stock split, abnormal return sesudah pengumumam stock split. Menurut Imam Ghozali (205), distribusi data dapat dilhat dengan membandingkan angka probalitas dengan taraf kesalahan (a) $=5 \%=0,05$. dengan kriteria sebagai berikut :

Jika angka $Z$ hitung $>Z$ tabel pada taraf signifikasi $5 \%$ sebesar 1,96 ; distribusi data tidak normal.

Jika angka $Z$ hitung $<Z$ tabel pada taraf signifikasi $5 \%$ sebesar 1,96 ; distribusi data normal.

Berdasarkan sampel yang ditetapkan sebanyak 32 sampel, setelah diuji normalitas dengan menggunakan kolmogorov-smirnov, dapat diketahui bahwa variabel yang terdistribusi normal adalah Trading volume activity sebelum stock split dengan nilai signifikasi kolmogorov-smirnov sebesar $0,218>0,05 ;$ abnormal return saham sebelum stock split dengan nilai signifikasi kolmogorov-smirnov sebesar 0,148>0,05; abnormal return saham sesudah stock split dengan nilai signifikasi kolmogorov-smirnov sebesar $0,516>0,05$, sedangkan variabel yang tidak terdistribusi normal adalah Trading volume activity sesudah stock split dengan nilai signifikasi kolmogorov-smirnov sebesar 0,008 $<0,05$. Data yang diperoleh dari BEI tidak berdistribusi normal, sehingga lebih sesuai menggunakan uji statistik non parametik (Wilcoxcon), sedangkan jika data nomal maka menggunakan uji parametric (Paried Sampel $t$ test). Mengacu pada Singgih Santoso (2004).

Pengujian uji beda antara Trading volume activity sebelum dan Trading volume activity sesudah pengumuman stock split diperoleh nilai signifikasi $0,024<0,05$. TVA 5 hari sebelum pengumuman stock split sebesar 0,00759438 lebih rendah dibandingkan Trading volume activity 5 hari setelah pengumuman stock split, yaitu sebesar 0,07143881 . Dengan demikian dapat diartikan bahwa ada perbedaan Trading volume activity sebelum dan Trading volume activity sesudah pengumuman stock split, sehingga hipotesis yang menyatakan terdapat perbedaan Trading volume activity sebelum dan Trading volume activity sesudah pengumuman stock split diterima.

Pengujian uji beda antara abnormal return saham sebelum dan bid-ask spread sesudah pengumuman stock split diperoleh nilai signifikasi $0,033<0,05$. Abnormal return 5 hari sebelum pengumuman stock split sebesar $-0,010688$ lebih rendah dibandingkan Abnormal return 5 hari setelah pengumuman stock split, yaitu sebesar 0,23021. Dengan demikian dapat diartikan bahwa ada perbedaan abnormal return saham sebelum dan abnormal return saham sesudah pengumuman stock split, sehingga hipotesis yang menyatakan terdapat perbedaan abnormal return saham sebelum dan abnormal return saham sesudah pengumuman stock split diterima.

\section{Pembahasan \\ Perbedaan TVA Sebelum Dan Sesudah Pengumuman Stock split.}

Dari hasil uji wilcoxon terdapat perbedaan trading volume activity sebelum dan sesudah pengumuman stcok split, hasil ini dibuktikan dengan nilai signifikasi 0,024 $<0,05$. Kondisi ini terjadi karena adanya stock split harga saham yang dulunya tinggi menjadi lebih murah sehingga investor tertarik melakukan investasi pada perusahaan tersebut hal ini tercermin Trading volume activity yang meningkat (split up), pengumuman stock split mengandung infomasi. Jika informasi tersebut menimbulkan reaksi pasar setelah pengumuman tersebut diterima oleh pasar. reaksi pasar ini dapat digunakan dengan trading volume activity yang terjadi di bursa efek indonesia. Hasil ini mendukung penelitian Johipura (2008), menyimpulkan bahwa jumlah pemegang saham menjadi bertambah banyak setelah split. Kenaikan 
tersebut disebabkan oleh karena adanya menurunnya harga volalilitas harga saham menjadi bertambah besar sehingga menarik investor untuk memperbanyak jumlah saham yang diperdagangkan.

\section{Perbedaan Abnormal Return Sebelum Dan Sesudah Pengumuman Stock split.}

Terdapat perbedaan abnormal return sebelum dan sesudah pengumuman stcok split, hasil ini dibuktikan dengan nilai signifikasi $0,033<0,05$. Kondisi ini terjadi karena adanya stock spit harga saham yang dulunya tinggi menjadi lebih rendah sehingga investor tertarik melakukan investasi pada perusahaan tersebut hal ini tercermin abnormal return meningkat,suatu pengumuman yang masuk ke bursa efek akan mempengaruhi pasar untuk beraksi. Jika suatu pengumuman mengandung information (information content), maka pasar akan melakukan reaksi pada waktu pengumuman tersebut. Reaksi pasar ini tercermin dari harga pasar yang berubahubah. Berdasarkan penelitian, Abnormal Return sebelum dan sesudah Stock split terdapat perbedaan karena harga pasar yang berubah - ubah sehingga pasar tidak efisien.

\section{SIMPULAN}

Terdapat perbedaan trading volume activity sebelum dan sesudah pengumuman stock split. Kondisi ini terjadi karena jumlah pemegang saham menjadi bertambah banyak setelah split. Kenaikan tersebut disebabkan oleh karena adanya penurunan harga volalilitas harga saham menjadi bertambah besar sehingga menarik investor untuk memperbanyak jumlah saham yang diperdagangkan. Berarti Pasar Modal di Indonesia Belum efectif dalam bentuk Setengah Kuat (Semi Strong) berdasarkan pengumuman Stock Split.

Terdapat perbedaan abnormal return sebelum dan sesudah pengumuman stcok split. Kondisi ini terjadi karena suatu pengumuman yang masuk ke bursa efek akan mempengaruhi pasar untuk beraksi. Jika suatu pengumuman mengandung information (information content), maka pasar akan melakukan reaksi positif pada waktu pengumuman tersebut, reaksi pasar ini tersermin dari harga pasar yang berubahubah. Berarti Pasar Modal di Indonesia Belum efectif dalam bentuk Setengah Kuat (Semi Strong ) berdasarkan pengumuman Stock Split.

\section{DAFTAR PUSTAKA}

Alfian, D. F. (2016). Analisis Perbandingan Trading Volume Activity Dan Abnormal Return Sebelum Sesudah Stock Split. Jurnal IImu Dan Riset Manajemen, 5 (5).

Beni, S. W. (2005). Analisis Empiris Perbedaan Kinerja Keuangan Antara Perusahaan yang Melakukan Stock Split Dengan Perusahaan yang Tidak Melakukan Stock Split : Pengujian The Signaling Hypotesis. Jurnal Akuntansi dan Manajemen, XVI (3) : $209-218$.

Carlos, G. A. and Frank, W. B. (2009). The Impact of Stock split Announcement on Stock Price:

A Test of Market Efficiency. Proceeding of American Society of Business and Behavioral Scienes Annual Conference, Las Vegas, 16 (1): 1-14

Fahmi, I. (2011). Analisis Laporan Keuangan. Cetakan Pertama. Alfabeta : Bandung.

Hendrawijaya, M. (2009). Analisis Perbandingan Harga Saham, Volume Perdagangan Saham,Dan Abnormal Return Saham Sebelum Dan Sesudah Pemecahan Saham (Studi Pada Perusahaan Go Public Yang Melakukan Pemecahan Saham Antara Tahun 2005 - 2008 di BEI). Program Pasca Sarjana Magister Sains Manajemen Undip, Tesis : tidak dipublikasikan.

Huang, G. C., Kartono, L. and Ming, S. P. (2002). Do Stock splits Signal Future Profitability?. 
http://Ssrn.com/abstract.315440. Diunduh 21 Maret 2014.

Husnan,Suad,1992.Efisiensi Pasar Modal Indonesia. Jurnal Ekonomi Indonesia,: 24-34

Jogianto. (2000). Teori Portofolio dan Analisi Investasi,Edisi 3. BPFE : Yogyakarta.

Jogiyanto. (2000). Teori Portofolio dan Analisis Investasi, Edisi 3. BPFE: Yogyakarta.

Jogiyanto. (2010). Studi Peristiwa,Menguji Reaksi Pasar Modal Akibat Suatu Peristiwa Edisi Pertama. BPFE : Yogyakarta.

Kalay, A. and Mathias, K. (2013). The Market Reaction to Stock splitAnnouncements: Earnings Information After All. http://Ssrn.com/abstract.14 Maret 2014.

Leung,T. Y.,et al. (2005). Do Stock Splits Really Signal?,PP.1-33

Marwata. (2001). Kinerja Keuangan, Harga Saham dan Pemecahan Saham. Jurnal Seminar Nasional Akuntansi III : 751 - 769.

Permata, N. (2012). Analisis Pengaruh Stock split Pada Harga Saham Terhadap Volume Perdagangan Di Bursa Efek Indonesia. Jurusan Ekonomi Pada Fakultas Ekonomi Universitas Gunadarma, Skripsi : tidak dipublikasikan.

Pramastuti, S. (2007). Analisis Kebijakan Dividend: Anteseden dan Dampaknya Terhadap Harga Saham. Jurnal Manajemen dan Kewirausahaan, 1:1-17.

Rudnicki, J. (2012). Further Evidence on the Impact of Stock splits on Trading Liquidity. Journal of Finance, : 1-11.

Suad, H. (2000). Corporate Governance di Indonesia: Pengamatan terhadap Sektor Corporate dan keuangan. Program Magister Hukum UGM Yogyakarta, Tesis : tidak dipublikasikan.

Suryantini, N. P. S. (2007). Perbedaan Kinerja Portofolio Berdasarkan Strategi Portofolio Aktif dan Pasif pada Saham LQ-45 di BEJ. Buletin Studi Ekonomi 12 (3): 299-313.

Wijanarko, I. (2012). Analisis Pengaruh Pemecahan Saham (Stock split) Terhadap Likuiditas Dan Return Saham (Studi Kasus Pada Perusahaan Yang Terdaftar Di BEI Periode 20072011). Sarjana Ekonomi Jurusan Manajemen Pada Fakultas Ekonomika Dan Bisnis Universitas Doponegoro, Skripsi : tidak dipublikasikan.. 